\title{
Sustainable Household Practices for Environmental Sustainability in Informal Settlements: Insights From Kanyama Ward 10, Lusaka, Zambia
}

\author{
Matildah Kapembwa \\ Department of Geography and Environmental Studies, University of Zambia, P.O. Box \\ 32379, Lusaka, Zambia
}

Tel: 260-977-399-017Ｅ-mail: kapembwamatildah@yahoo.com

\begin{abstract}
Kabwe Harnadih Mubanga
Department of Geography and Environmental Studies, University of Zambia, Lusaka, Zambia
\end{abstract}

Tel: 260-953-749-606 E-mail: kabwe.mubanga@live.com

Received: November 22, 2020 Accepted: January 22, 2021 Published: January 27, 2021

doi:10.5296/jee.v12i1.18257

URL: https://doi.org/10.5296/jee.v12i1.18257

\begin{abstract}
This study on sustainable household practices for transforming environmental concerns into environmental solutions in informal settlements was conducted in Kanyama Ward 10, Zones 98 and 100, Lusaka District. The study identified household practices among residents that could contribute to enhancing household environmental sustainability and assessed the costs and resident's willingness to pay for household greening. Data were collected using structured interviews administered to 145 residents and interview guides for 11 key informants. Quantitative data were analysed using chi-square, two-sample t-test and the Pearson Product Moment correlation, while qualitative data was analysed using thematic analysis. The results showed that the major environmental concerns in Zones 98 and 100 of Kanyama Ward 10, prioritised from the resident's point of view included waste management with $79 \%$ in Zone 100 and $82 \%$ in Zone 98, flooding $67 \%$ in Zone 100 and $80 \%$ in Zone 98 and poor drainage system $51 \%$ in Zone 100 and $59 \%$ in Zone 98 . Some of the household practices by residents capable of enhancing environmental sustainability were identified as maintaining sanitary home environment at $42 \%$ in Zone 98 and 61\% in Zone 100, disposing waste in bins $11 \%$ in Zone 98 and $15 \%$ in Zone 100 and planting trees/vegetables $7 \%$ in Zone 98 and $24 \%$ in Zone
\end{abstract}


100. Results show that more sustainable household practices in Zone 100 resulted in reduced environmental concerns. There was a significant positive correlation between household practice cost incurred for greening and average monthly income earned by respondents $(\mathrm{r}=$ $0.500 ; \mathrm{p}<0.05$ ). This meant that households with higher monthly household incomes spent more on household greening. Furthermore, household income levels had an insignificant effect on the resident's willingness to pay for household greening $\left(X^{2}=0.781, \mathrm{p}=0.321\right)$.

In conclusion, resident's engagement in sustainable household practices and willingness to pay for greening in informal settlements was significantly influenced by their levels of household income as there was a relationship between the level of income and cost of environmental sustainability. Residents' attitudes towards household greening and levels of income could prove to be either a hindrance or motivating factor in achieving environmental sustainability. As such, the study recommended sensitization, providing entrepreneurship skills and behavioural change campaigns in the area in order to instil the importance of household greening and improve their levels of income.

Keywords: Environmental solutions, Greening, Household practices, Environmental concerns, Willingness to pay

\section{Introduction}

Informal settlements are illegally developed residential areas that lack the consent of the concerned municipal authorities. They are usually established through self-help processes by people who illegally occupy premises or land and build their houses on such land [World Bank and United Nations Centre for Human Settlements (UNCHS), 2007]. Inhabitants of informal settlements live in a permanent state of illegal and social insecurity that lack legal recognition due to unlawful occupation and or unauthorised use of land and or illegal construction of houses upon the land (URP Act No. 3 of 2015 of Government of Zambia). Srivinas (2003) in Olajide (2010) also defined informal settlements as being characterised by the illegal occupation of private or vacant land, unauthorised subdivision and construction of buildings and structures, reliance on low-cost and locally available scrap construction materials and the absence of restrictive regulations and standards. This often leads to overcrowding and deterioration of the environment, and insufficient basic needs such as water, sanitation and solid waste management, which often endangers residents' health and the environment. Further, informal settlements are often characterised by poverty, which plays a major role in preventing them from acquiring service delivery to improve the environment they reside in (Lohern 2011). According to UN-Habitat (2010), over $60 \%$ of the urban population in Africa is estimated to reside in informal settlements. Informal settlements are generally associated with environmental degradation. Bai and Dent (2009:150) stated that "environmental degradation is a long-term loss in ecosystem function and productivity from which the land cannot recover unaided, requiring progressively greater inputs to repair the damage".

Informal settlements have grown considerably in recent years in Zambia, and are characterised by poor water supply and sanitation issues (Ministry of Local Government, 2011). Several factors exacerbate environmental issues common in informal settlements. For example, intermittent water supply usually for several hours each day which compromises household sanitation, health, disease and increased spending on health care which may deplete household savings (Moosavi, 2011; Hunter et al 2010; Mutesu, 2015). Further, a lack of municipal 
services contributes to indiscriminate solid waste disposal around the houses with waste remaining uncollected for long periods (Gutberlet 2016). The general failure to uphold good practices by households in informal settlements through sustainable household practices exacerbates impacts felt through environmental mismanagement. Sustainable household practices demand households' lifestyle practices that are better for communities and the environment in both the short and long term. The practices could include sustainable water conservation, reduced generation of waste, and waste separation with possible recycling, reusing and planting more trees (Rinkesh, 2009). Unsustainable household practices may include illegal dumping and burning of household solid waste, and indiscriminate solid waste disposal which contributes to environmental problems ranging from land, water and air pollution (Nkwachukwu et al., 2010; Kaundal and Sharma, 2007).

Environmental concerns in informal settlements are usually a product of a lack of service provision from the local government (due to the unplanned nature of the settlements) and the resident's failure to develop environmentally friendly practices. Hence, solutions to the residents' environmental challenges should be locally driven and should start with the residents' attitudes towards environmental sanitation. Common environmental challenges in informal settlements in Zambia relate to unsustainable disposal of faecal matter, indiscriminate disposal of household solid waste and open burning of waste. Šmejkalova et al. (2003) indicated that the practice of burning waste has a negative impact on the biodiversity of the area. A lack of sustainably managed landfills and inadequate solid waste management in informal settlements of Lusaka is both a sanitary concern as well as an environmental concern. However, environmentally friendly household practices can provide solutions to such vices which begins by changing people's attitude and behaviour towards their environment and sanitation of their surroundings. This study sought to identify specific household environmental practices in Kanyama Ward 10 that could contribute to the transformation of the area into an environmentally friendly one.

The study was aimed at assessing the sustainable household practices among residents in informal settlements in Zones 98 and Zone 100 of Kanyama Ward 10 Township in Lusaka that could contribute to the transformation of environmental concerns into environmental solutions. The study objectives were twofold; (i) To identify household practices capable of enhancing or hindering environmental sustainability in Kanyama Township and (ii) To assess the cost of transforming selected household environmental issues into environmental solutions.

\section{Description of the Study Sites - Zones 98 and Zone 100 of Kanyama Ward 10}

Kanyama Ward 10 is in Kanyama Constituency in Lusaka District and lies between latitude (12E, 16E) and longitude (23S, 27S) (Figure 1). The settlement is located $4.5 \mathrm{~km}$ West of Lusaka Central Business District (CBD) and within the proximity of the industrial areas (Mwape, 2007). Zone 98 in old Kanyama and Zone 100 in newly developed areas of Kanyama Ward 10 areas were purposively selected from the 19 Zones of Kanyama Ward 10 as they represented areas with varying economical characteristics, with Zone 98 being a low-income area while Zone 100 was a high-income area.

Poverty levels in Zone 98 were high as residents depended on small informal businesses mostly done at their homes, and informal employment such as casual work and petty trade. Houses were densely populated with no access roads. The area is overpopulated with over 2500 
households on a 600,000 square meters area, that is, on average $15 \mathrm{~m} \times 15 \mathrm{~m}$ plot per household (Google Earth, 2019). Most residents are low-income tenants who pay as low as ZMW 70 (US\$ 5) per month for a one-roomed house. Water and sanitation are communal and shared among residents. Residents were exposed to increased crime and social risks such as prostitution, theft as well as public nuisance through drunken stupors.

On the other hand, Zone 100 is a high-residential area with big house plots with proper access roads. It is sparsely populated as compared to Zone 98 with about 500 households on approximately 400,000 square meters, that is, on average $40 \mathrm{~m}$ x 20m each plot (Google Earth, 2019) which is above the medium cost plot sizes requirement. Residents in Zone 100 are mostly house owners who are engaged in formal employment or thriving businesses. Hence, their economic status and education levels were higher than those in Zone 98. Sanitation conditions were better in Zone 100 with residents utilising piped water and sewer systems, which was contrary to Zone 98 where most residents utilised pit latrines and shallow wells or communal taps and kiosks.

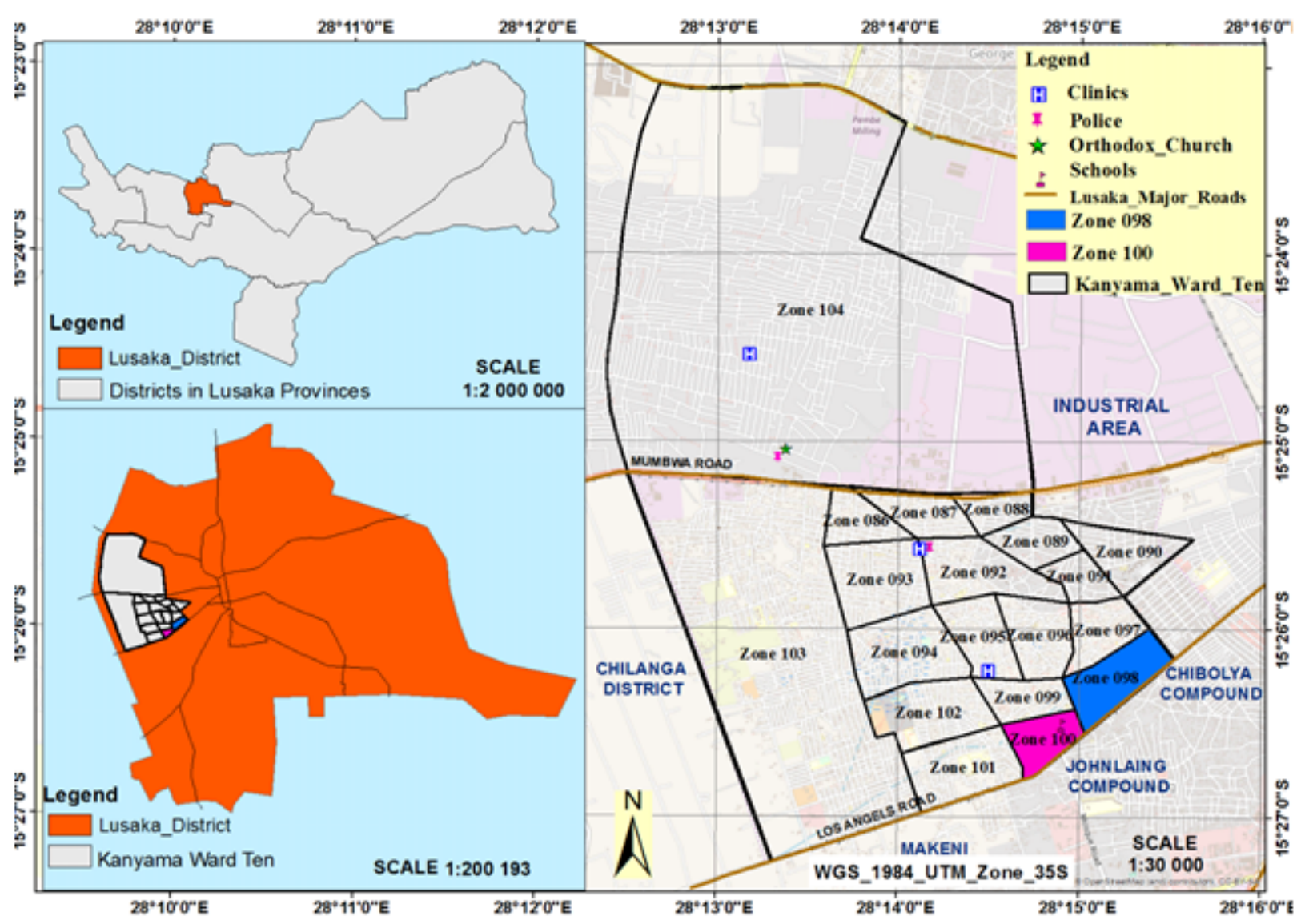

Figure 1. Map showing the location of Zone 98 and Zone 100 in Kanyama Ward 10 settlement in Lusaka, Zambia

\section{Methods}

This study employed a mixed-method approach (Bryman, 2012) involving both qualitative and quantitative techniques. The study was a comparative study of household practices that could 
enhance or hinder environmental sustainability among low and high residential areas represented by Zones 98 and 100 of Kanyama Ward 10, respectively.

\subsection{Sampling}

Kanyama Ward 10 has 19 Zones from which Zones 98 and 100 were sampled using purposive sampling based on their levels of income. Households for respondent interviews were sampled using simple random sampling by giving an equal chance of inclusion in the sample to all the households by assigning random numbers then conduct a raffle (Kothari, 2004). The sample size of 145 households was determined through a prior analysis using the software G-power 3.2 (Erdfelder et.al., 1996). The software provided a statistical power of 0.96 for detecting moderate effect size at 0.05 level of significance. Eleven key informants were sampled purposively based on their knowledge, relationships and expertise regarding environmental sustainability in the study area (Freedman et al., 2007).

\subsection{Data Collection}

The study used both primary and secondary data. Primary data was obtained from the field through structured interviews with respondents, key informant interview guides and observations. Secondary data was obtained through desk research.

\subsubsection{Semi-Structured Interviews}

A semi-structured interview is a hybrid, moderate and combination of the structured and unstructured interviews, which means that some questions are predetermined, while others arise spontaneously in a free-flowing conversation (Kothari, 2004). This research used a semi-structured interview to collect data on the sustainable and unstainable household practices employed by the residents and to evaluate the cost for transforming environmental issues into environmental solutions. This method allowed the researcher to collect information and people's perceptions on the sustainable household practices that enhance environmental sustainability and to estimate the cost for transforming each environmental concern into environmental solution because it dealt with household practices and behaviour to their environment.

\subsubsection{Key Informant Interviews}

Unstructured Interviews were also employed in gathering information from key informants such as Zone leaders from the Ward Development Committee, Lusaka City Council (LCC) officers. It involved face to face conversations between the researcher and the key informants to identify environmental issues that hinder environmental sustainability and to evaluate the cost that had been incurred to transform the identified environmental issues into environmental solutions in Kanyama Ward 10.

\subsubsection{Observation}

Observation is a method of data collection where the information is sought by way of investigators' direct observation without asking from respondents (Kothari, 2004). The non-participant observation was used throughout the field and photographs were taken from observed sites. The method facilitated the availability of information which was not provided by other data collection methods. It was also used to validate the information on the environmental issues in the study area gathered by other data collection methods that were employed in the field. 


\subsubsection{Desk Research}

Desk research was used to collect data through a literature review. Data reviewed related to information about informal settlements, environmental issues, environmental sustainability and greening strategies that formed the basis of the study. Further, data on demographic information related to Kanyama Township was also collected through desk research and google Earth 2019 was used to collect data on settlement patterns of Zones 98 and 100 of Kanyama Ward 10.

\subsection{Data Analysis}

Correlations involving mean monthly household incomes for residents of Kanyama Ward 10 and the mean costs for transforming environmental concerns into environmental solutions was done using the Pearson Product Moment (r). Two sample t-test was used to estimate differences in the mean monthly income levels of the residents in the two selected Zones and to estimate the mean costs incurred to transform households' environmental concerns into environmental solutions. Simple regression analysis was used to establish relationships between residents' monthly incomes and the cost for greening. Non-probability data was analysed using thematic analysis. According to Moore and McCabe (2005), in thematic analysis, data gathered is categorised in themes and sub-themes in order to determine the most frequently occurring themes. The advantage of thematic analysis is that it helps the data collected to be simplified to specific themes or topic, while at the same time producing results that may then be measured using quantitative techniques. All statistical operations were conducted in SPSS 23 and Microsoft Excel 2013 at probability level, $\mathrm{P}=0.05$.

\section{Results}

\subsection{Demographic Information}

Majority of respondents (67\%) were self-employed in the informal sector, with only $25.3 \%$ employed in the formal sector (Table 1). Many of the respondents were in their prime age (30-39), although there was an inclusion of older respondents (50 years and above) who had stayed in the settlement for more than 30 years and had more experience on the environmental issues of the area. Regarding literacy levels, 19\% of the respondents had attained tertiary education, 39\% secondary level, 38\% primary level and 3\% hardly attained any education, indicating that the majority of the respondents were literate and aware of what environmental issues were because it is a subject learnt at elementary education levels. 
Table 1. Demographic characteristics of respondents in Zones 98 and 100 of Kanyama Ward 10, 2018

\begin{tabular}{|c|c|c|c|c|c|c|}
\hline Age & \multicolumn{2}{|c|}{ Frequency } & Percentage & Gender & Frequency & Percentage \\
\hline $20-29$ & \multicolumn{2}{|c|}{39} & 26.9 & Male & 58 & 40 \\
\hline $30-39$ & \multicolumn{2}{|l|}{51} & 35.3 & Female & 87 & 60 \\
\hline $40-49$ & \multicolumn{2}{|l|}{32} & 22 & Marital status & Frequency & Percentage \\
\hline $50-59$ & \multicolumn{2}{|l|}{19} & 13.1 & Married & 97 & 67 \\
\hline $60-69$ & \multicolumn{2}{|l|}{3} & 2 & Single & 48 & 33 \\
\hline $70-79$ & \multicolumn{2}{|l|}{1} & 0.7 & $\begin{array}{l}\text { Sample } \\
\text { site }\end{array}$ & Frequency & Percentage \\
\hline Education status & $\begin{array}{l}\text { Frequ } \\
\text { Zone } \\
100\end{array}$ & $\begin{array}{l}\text { Zone } \\
98\end{array}$ & Percentage & Zone 100 & 74 & 51 \\
\hline Primary & 15 & 40 & 38 & Zone 98 & 71 & 49 \\
\hline Secondary & 38 & 19 & 39 & $\begin{array}{l}\text { Employment } \\
\text { status }\end{array}$ & Frequency & Percentage \\
\hline Tertiary & 23 & 5 & 19 & Employed & 37 & 25.3 \\
\hline $\begin{array}{ll}\text { No formal } \\
\text { schooling }\end{array}$ & 2 & 3 & 3 & $\begin{array}{l}\text { Self } \\
\text { employed } \\
\text { Unemployed }\end{array}$ & $\begin{array}{l}97 \\
11\end{array}$ & $\begin{array}{l}67 \\
7.5\end{array}$ \\
\hline
\end{tabular}

4.2 Household Practices That Either Hinder or Promote Environmental Sustainability in Kanyama Township, Lusaka

Unsustainable household practices hindering environmental sustainability were common in the two zones under study (Figure 2). Burning of waste (41\% in Zone 98; 39\% in Zone 100) was the most common unsustainable household practice in both Zones 98 and 100 of Kanyama Ward 10, while the use of firewood was the least common (3\% in both Zones). Disposing of waste in drainages and untreated toilets were the second most common unsustainable environmental household practice in Zone 98 (at 21\%), though not as common in Zone 100 (14\% and $11 \%$ respectively) (Figure 2). 


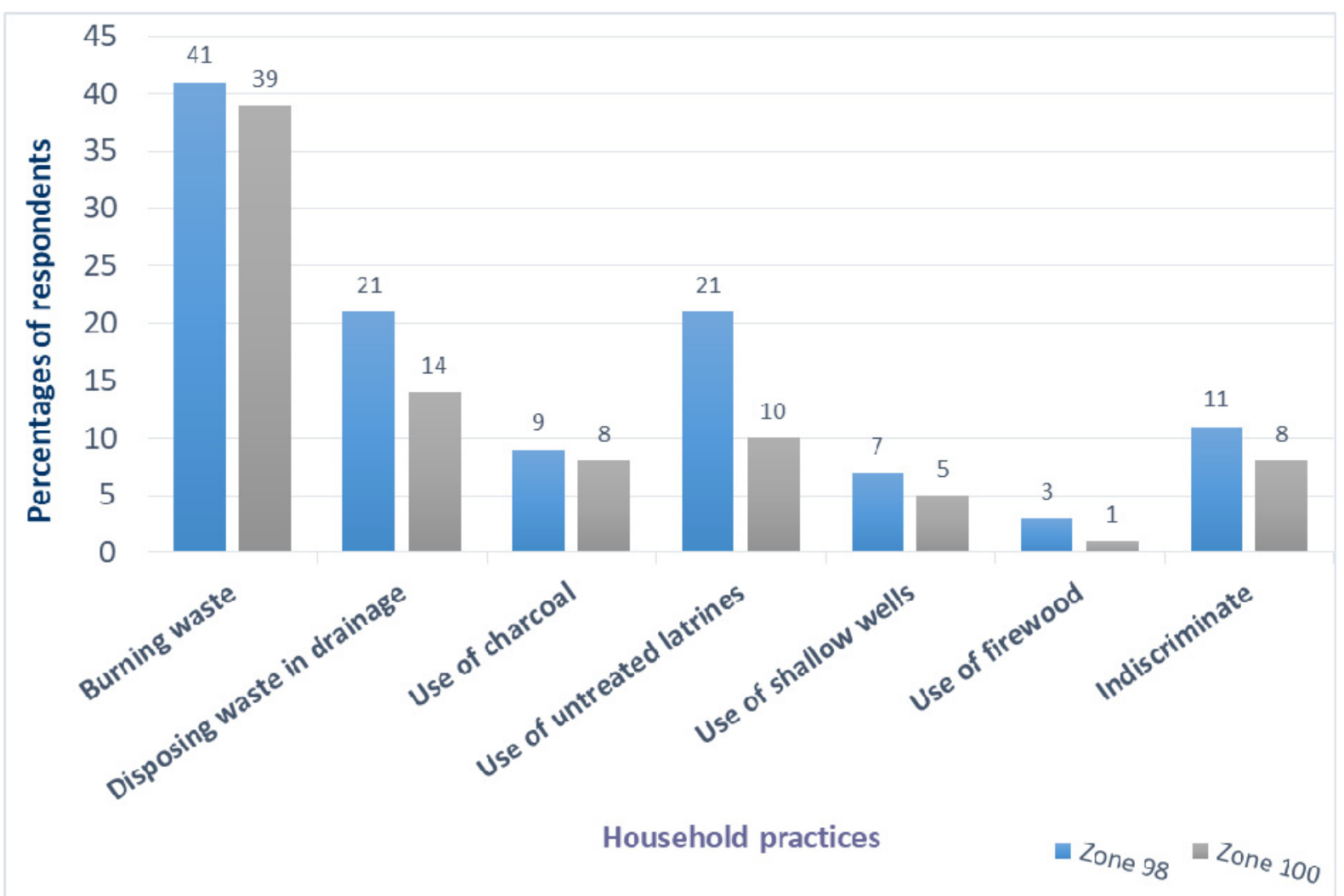

Figure 2. Unsustainable household practices hindering environmental sustainability in Kanyama Ward 10, Lusaka as of 2018

Key informant interviews with the area councillor and the Ward Development Committee (WDC) representative revealed reasons as to residents' failure to maintain the environmental sustainability. These included the lack of transport for waste disposal from households to the dumpsite. The available two tractors were said to be unable to go around the entire Ward due to its extensive coverage. The Ward leaders and an Environmental Planner at Lusaka City Council in charge of the area stated that they engaged eight community-based entrepreneurs (CBEs) who also facilitated in the waste collection at a monthly fee of US\$ 6 . Even this was still not adequate for the entire ward as some households could not be reached due to inaccessible roads and the very high population. Some households were reportedly refusing to pay the monthly charge and resorted to disposing of waste in drainages which led to blockages of the drainage system, as well as burning of waste and indiscriminate disposal of waste, which was also an environmental hazard (Figure 3) 


\section{Ml Macrothink}

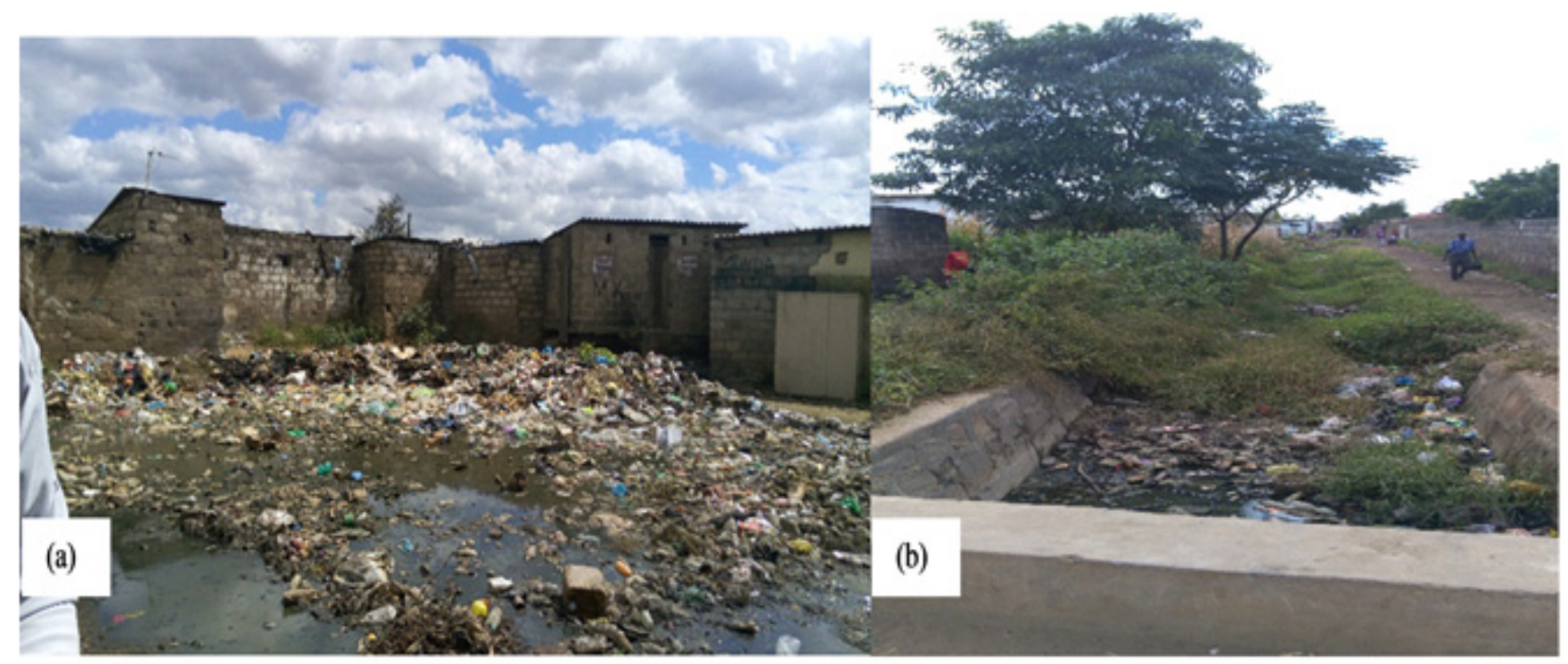

Figure 3. Showing a) Burning /indiscriminate waste disposal and b) Waste disposal in the drainage resulting in blockage of the drainage in Zone 98 of Kanyama Ward 10, Lusaka, 2018

And the key informant from Lusaka Water Trust said that;

"The Ward lack private sector involvement in the provision of adequate water and sanitation, hence residents depend on water from shallow wells and individually drilled boreholes and use pit latrines which are not environmentally sustainable"

When asked on why they were still using shallow wells (Figure 4) as a source of water despite the government issuing an order to have them closed, residents said that they did not see anything wrong with that, since they had been using them for a long time. Wells provided a solution to the scarce water supply in the area they said.

A male respondent aged 58 said this

"Uyu mugodi wanga wanitandiza maningi pa zaka zambili. Nimasebenzesa manzi aya kumwa, kupikila na kuchapa. Siningaleke kusebenzesa aya manzi” meaning "my well has been of help to me for many years. It has been helping me with water to drink, clean my clothes and cooking. I cannot stop using this well" 


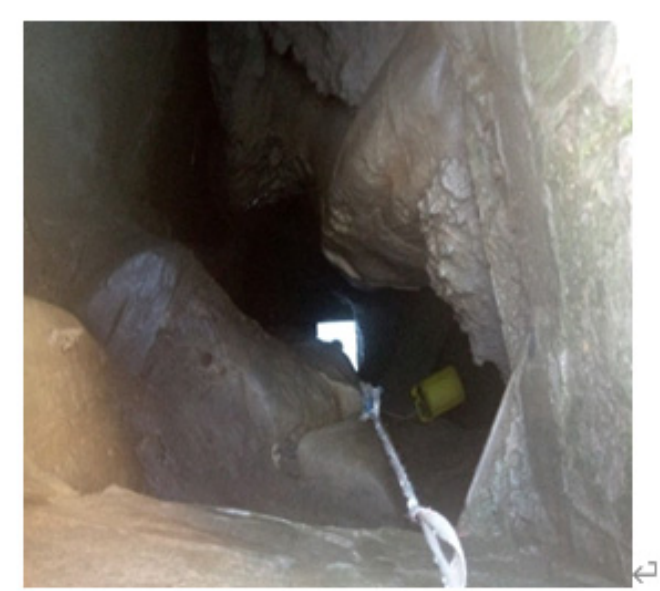

(a)

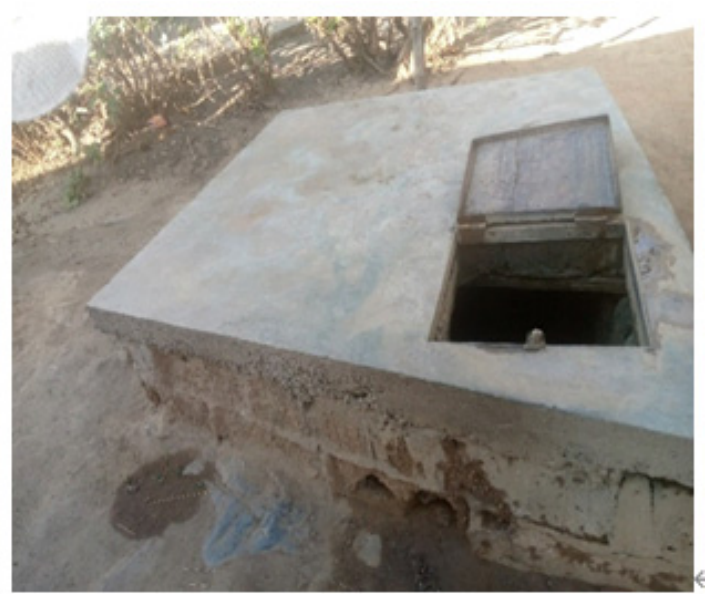

(b)

Figure 4. Shallow wells for water supply for residents in Zone 98

\subsection{Household Practices That Promote Environmental Sustainability in Kanyama Township}

Cleaning of the surrounding (42\% in Zone 98; 61\% in Zone 100) was the commonest sustainable household practice in Zones 98 and 100 of Kanyama Ward 10 promoting environmental sustainability while the use of solar lights was the least common household practice (1\% in Zone 98; 3\% in Zone 100) (Figure 5). More residents in Zone 100 were engaged in environmentally sustainable household practices than in Zone 98.

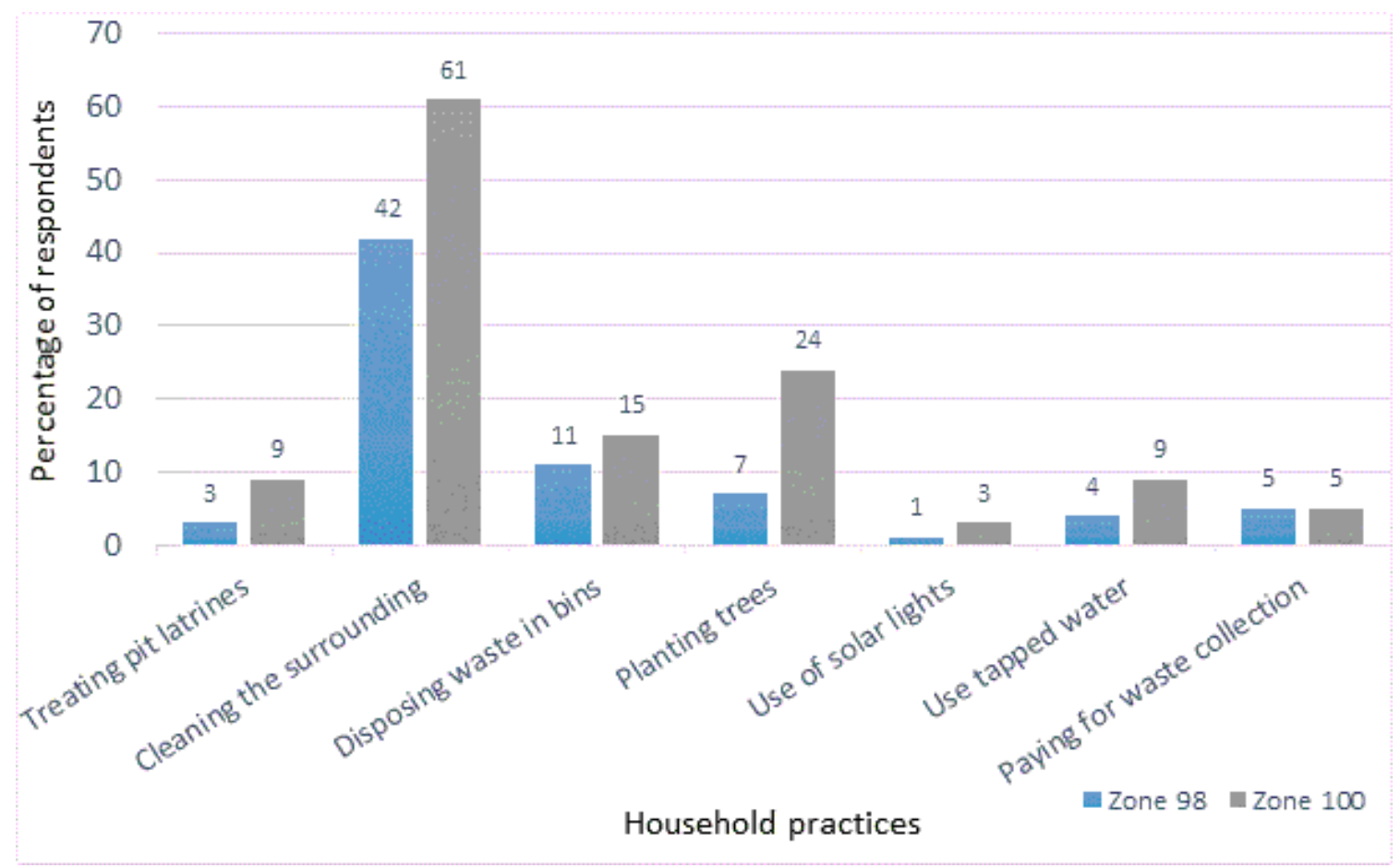

Figure 5. Sustainable household practices that would transform environmental concerns into environmental solution in Zones 98 and 100 of Kanyama Ward 10, Lusaka in 2018 


\section{Macrothink}

4.4 Cost of Transforming Selected Household Environmental Issues Into Environmental Solutions

The mean monthly incomes for residents in Zone 100 was significantly higher than that of the residents in Zone $98(\mathrm{t}=6.46 ; \mathrm{p}=0.0001)$ using a one-tailed two-sample t-test (Table 2). Residents in Zone 100 (mean= ZMW 2877; Range $=$ K8000) earned significantly more than the residents of Zone 98 (mean $=$ ZMW 1095; Range $=$ K2000) (Figure 6). The difference in monthly income shows that the economic status of the residents in Zone 100 was greater than the economic status of residents in Zone 98 hence the difference in environmental issues and sustainable household practices.

Table 2. Two-Sample T-Test for monthly incomes for residents in Zone 100, Zone 98 of Kanyama Ward 10

\begin{tabular}{llllllll}
\hline Sample & N & Mean & StDev & SE Mean & T-Value & DF & p-value \\
\hline Zone 100 & 74 & 2877 & 2264 & 263 & 6.46 & 86 & 0.0001 \\
Zone 98 & 71 & 1095 & 704 & 82 & & & \\
\hline
\end{tabular}

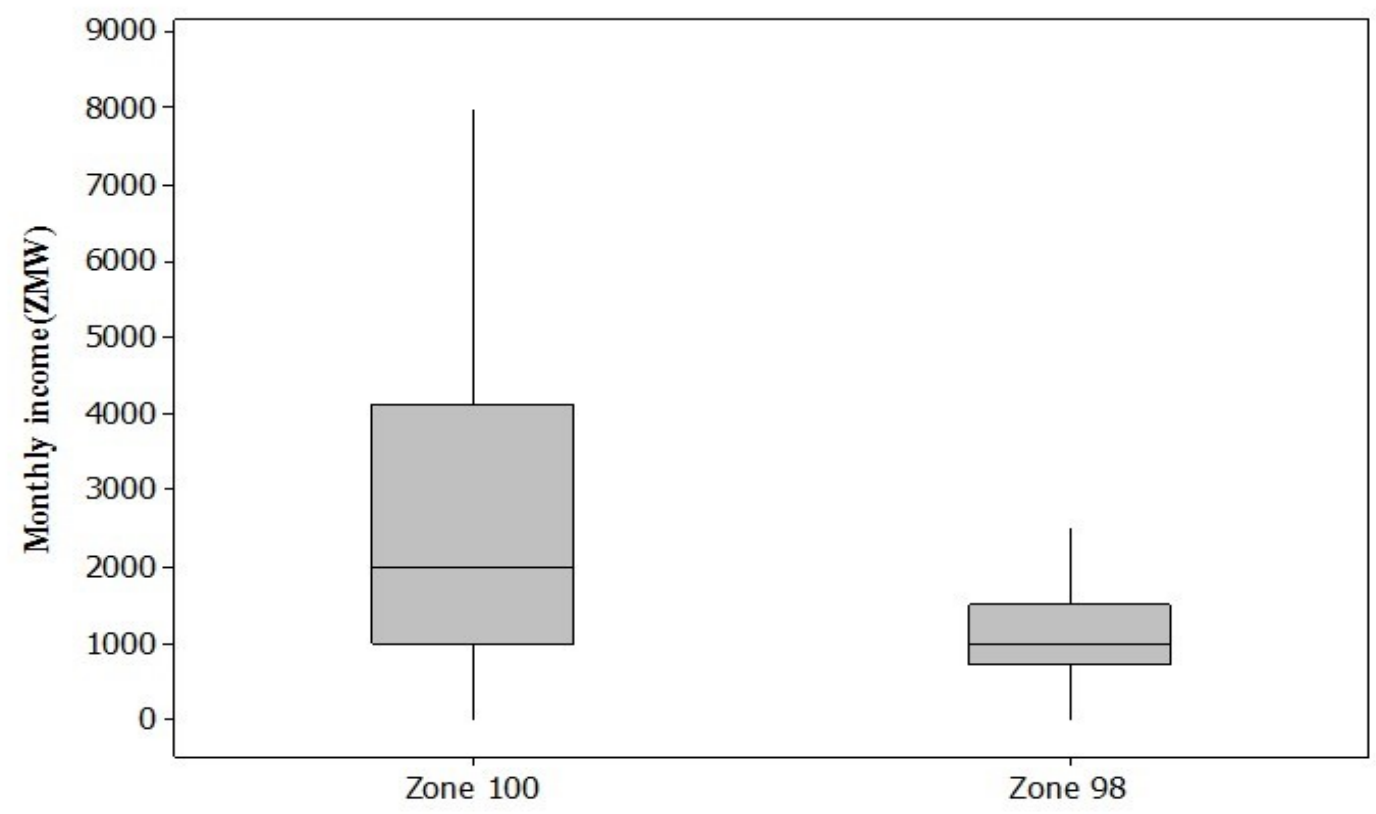

Sampled residential area in Kanyama Ward 10

Figure 6. The difference in mean monthly income for residents in Zones 98 and 100 in Kanyama Ward 10 as of 2019 


\subsection{Cost of Transforming Environmental Concerns}

Just like the monthly income for residents in Zone 100 was greater than that of the residents in Zone 98 (Figure 7), the cost for transforming environmental concerns into environmental solutions was also greater for residents in Zone 100 than residents in Zone $98(\mathrm{t}=4.89$; $\mathrm{p}=$ 0.0001) (Table 3).

Table 3. Two-Sample T-Test for the cost for transforming environmental concerns in Zone 100, Zone 98

\begin{tabular}{llllllll}
\hline Sample & $\mathrm{N}$ & Mean & StDev & SE Mean & T-value & DF & P-Value \\
\hline Zone 100 & 45 & 63.0 & 37.5 & 7.5 & 4.89 & 27 & 0.0001 \\
Zone 98 & 15 & 25.12 & 9.66 & 1.9 & & & \\
\hline
\end{tabular}

This implies that residents in high-income residential areas pay more for their environmental sustainability than those from low-income residential areas. When asked on how much residents paid to transform their households into environmentally sustainable ones, residents in Zone 100 were found to pay more (mean $=$ ZMW 63) than residents in Zone 98 (mean $=$ ZMW 25.12) (Table 3). Costs for waste collection and treating toilets were paid monthly because they were done monthly. However, costs for waste bins, planting tree /vegetables and solar lights were paid for periodically as the need arose by residents but monthly estimates where done in this study (Table 4).

Table 4. Mean amounts apportioned towards environmental solutions in Zone 98 and Zone 100 of Kanyama Ward 10, Lusaka as of 2018

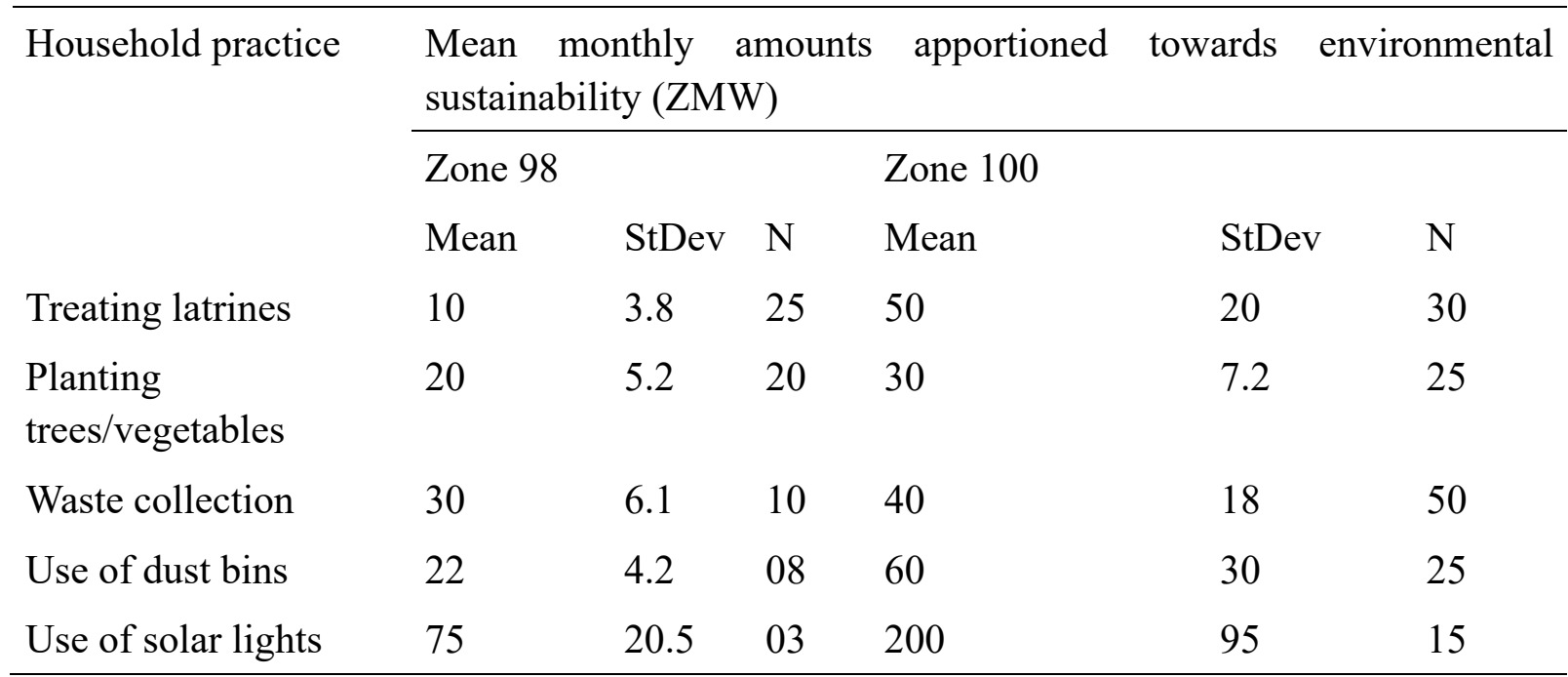




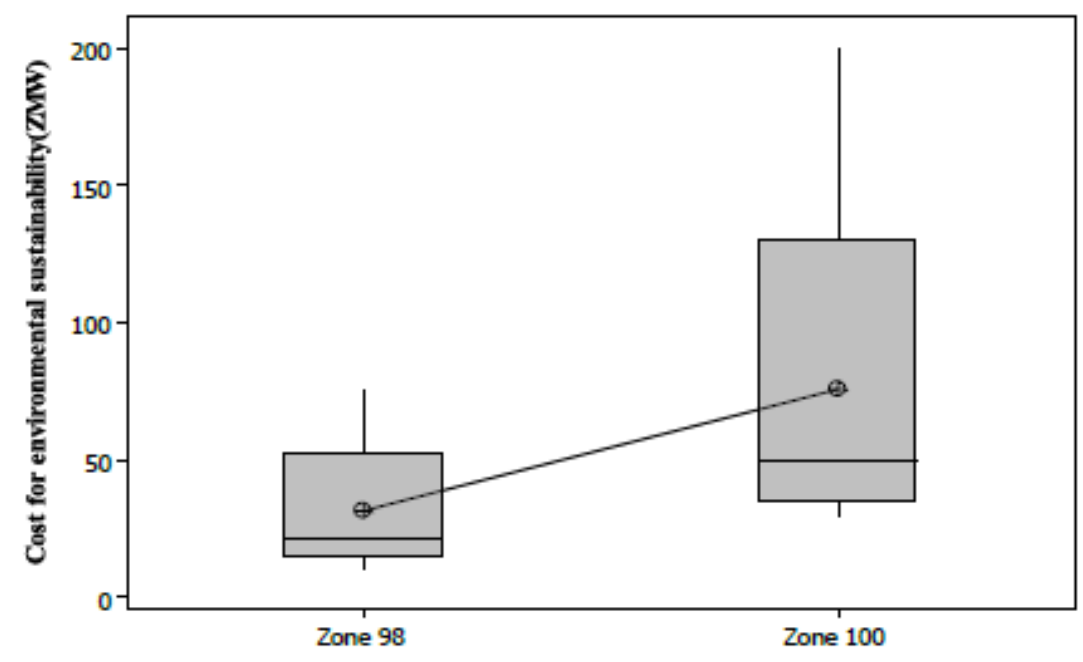

Residential area in Kanyama Ward 10

Figure 7. Mean monthly costs for greening in Zone 98 and Zone 100 of Kanyama Ward 10 as of 2018

There was a statistically significant difference between the mean cost for waste bins $(\mathrm{t}=-4.62$; $\mathrm{p}=0.001)$, planting trees / vegetables $(\mathrm{t}=-6.83 ; \mathrm{p}=0.001)$ and treating toilets $(\mathrm{t}=-2.29 ; \mathrm{p}=$ 0.035) in Zone 98 and Zone 100 (Figure 8 a-e). Residents in Zone 100 utilised expensive waste bins and paid for formal waste collection, while those in Zone 98 utilised relatively smaller and cheaper waste bins and commonly utilised informal waste collectors for their waste collection. The prevalent use of informal waste collectors in Zone 98 could have contributed to the indiscriminate waste disposal common in the area. This problem was not as prevalent in Zone 100. There was a difference in the monthly cost for solar lights ranging from ZMW 175 to ZMW 275 in Zone 100 while in Zone 98, the range was from ZMW 70 to ZMW 90 per month (Figure 8c). This was because many residents in Zone 98 utilised relatively smaller and cheaper solar lights compared to the ones utilised in Zone 100. However, only a few households in both Zones (1\% in Zone 98 and 3\% in Zone 100) had any real interest in using solar lights which was a more environmentally sustainable energy source.

A female 38-year-old respondent in Zone 98 said:

"I use charcoal and firewood for cooking and candles for lighting instead of solar energy because they are cheaper and manageable. I don't even know how solar energy can be used for cooking and lighting".

Treating toilets in Zone 100 costed an average of ZMW 50 and ZMW 10 in Zone 98 (Figure 8d). This was because residents in Zone 100 indicated that they were using chemicals from formal traders to treat their toilets than residents in Zone 98 who said that they bought chlorine and chemicals from street vendors. The cost for planting trees was also slightly higher in Zone 100 (mean=ZMW 30) than Zone 98 (mean=ZMW 20) (Figure 8e) because the researcher observed that residents of Zone 100 commonly bought different species of trees and plants, many of 
which were exotic, while residents of Zone 98 mainly planted vegetables and very few were observed to have planted trees.
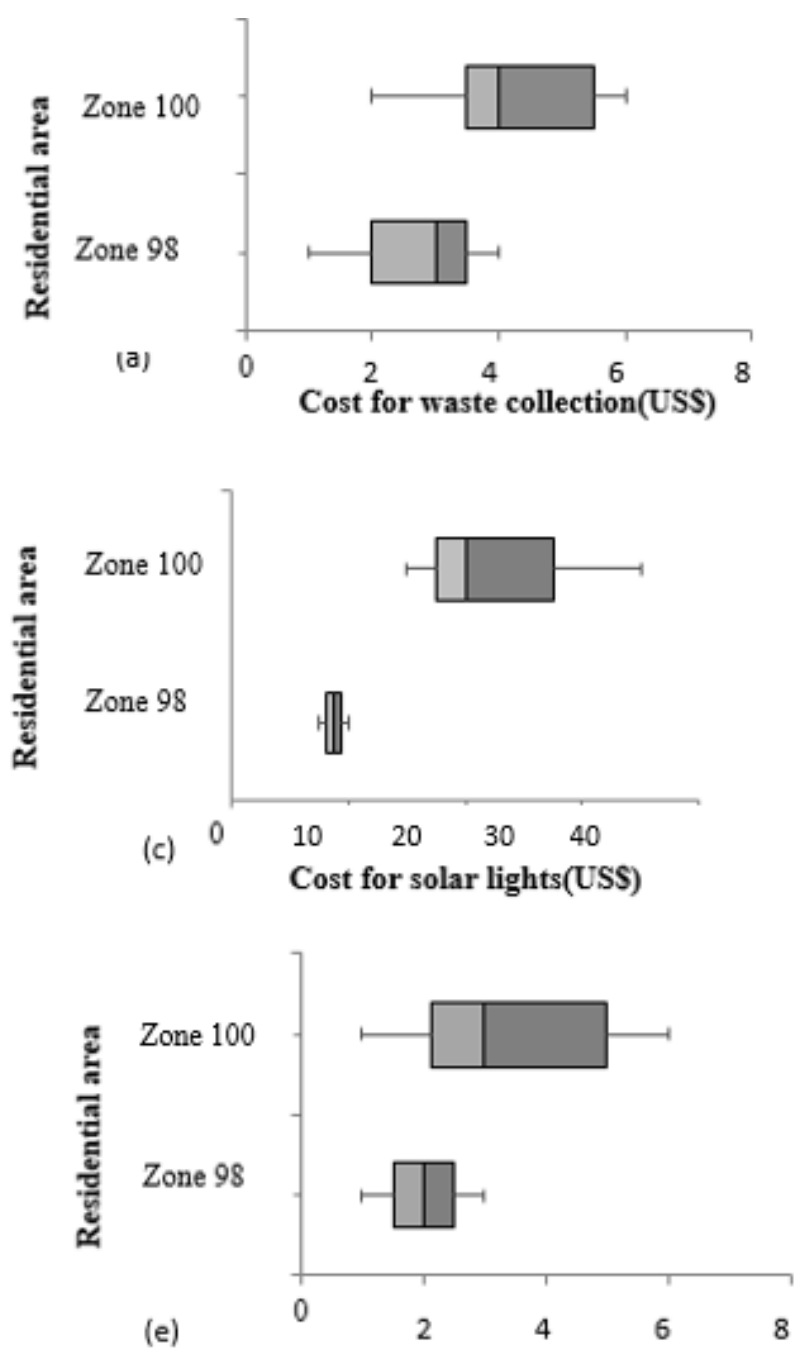

Cost for planting trees/vegetables(US\$) (b)

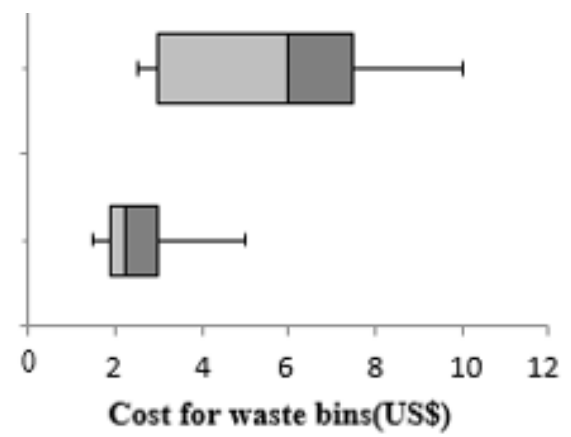

(d)

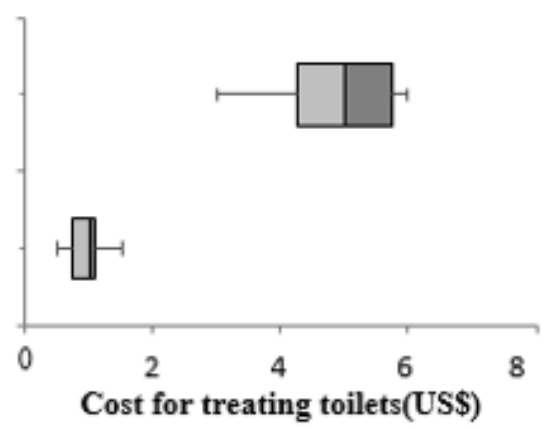

Figure 8. Box and whisker plot showing the mean monthly costs for a) waste collection b) waste bins c) buying solar lights d) treating the toilets and e) planting plants/vegetable in Zones 98 and Zone 100 of Kanyama Ward 10 as of 2018 The extreme ends of the boxes are the upper and lower quartiles, box heights are interquartile ranges, the top and bottom whiskers represent the amount of money residents spent on transforming their households' environmental concerns into environmental solutions in a particular month. The vertical lines in each box are the estimated median cost of environmental sustainability per month/household.

Further, most residents in Zone 98 where tenants and felt they were not responsible for planting trees which they would leave when they shift. The feelings of these respondents were summarised by one respondent who said:

"sininga shange mitengo panyumba yamene si anga, nikakuka nikasiyile benango" 


\section{Macrothink

(Translated as "I cannot plant trees on a rented house of which when I leave, someone else would come and benefit").

\subsection{Cost of Household Environmental Sustainability and Mean Monthly Income for Kanyama} Residents

There was a significant positive correlation (Zone 98: $r=0.94 ; p=0.001$ Zone 100: $r=0.599$; $\mathrm{p}=0.001$ ) between monthly income and the cost for waste collection in both Zones (Figure 9 $\mathrm{a}-\mathrm{h})$. This meant that the monthly income of the residents determined how much one would pay for waste collection at the minimal rate of ZMW 25 for Zone 98 and ZMW 67 for Zone 100 per month. Likewise, on the cost for treating toilets, a negative correlation in Zone $98(\mathrm{r}=-0.642 ; \mathrm{p}$ $=0.001)$ meant that the higher the monthly income of the resident the lower the amount they spent on treating their toilets at the rate ZMW 148 per month (Figure 9d) as they said that treating toilets was not a priority as compared to buying food for their families.

A female married respondent from Zone 98 aged 38 said this

"Life is expensive nowadays, hence treating toilets is not as important as buying food for my children. I just pour ashes from the brazier in the toilet as a way of treating it"

A significant positive correlation in Zone $100(\mathrm{r}=0.475 ; \mathrm{p}=0.01)$ (Figure $9 \mathrm{~h})$ meant that the higher the monthly income of the resident the higher the mean monthly cost for treating the toilets at the rate of ZMW 41 per month.

A male married respondent from Zone 100 aged 42 said this

"I buy toilet treating chemicals from Shoprite or pick and pay because I find them to be more effective"
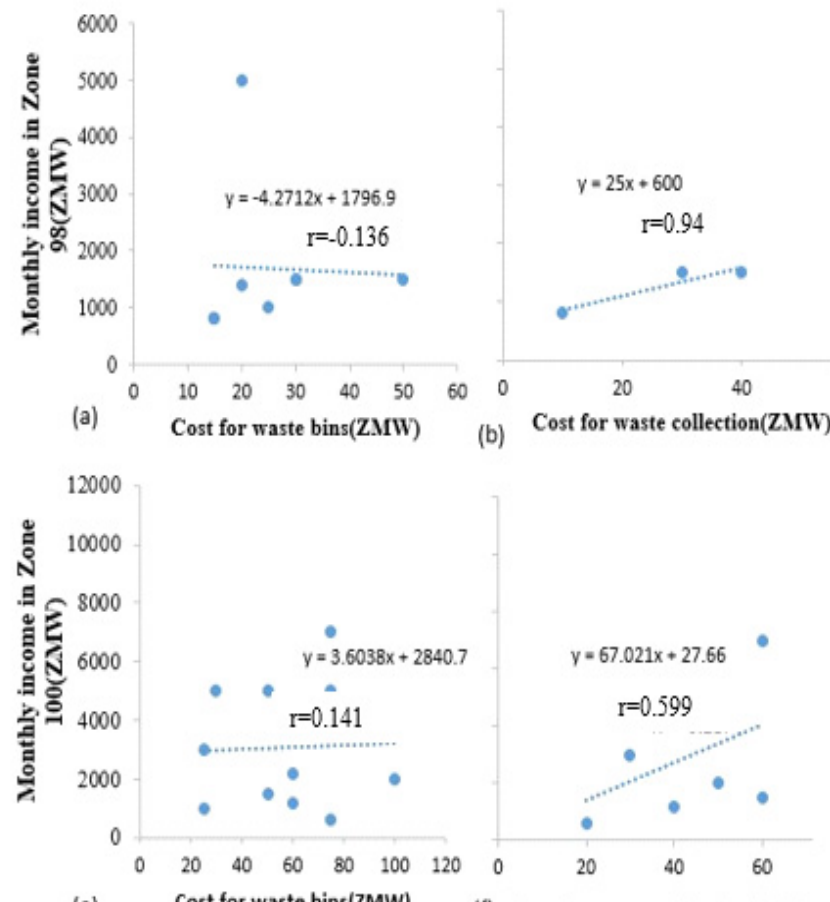

(e) (b)

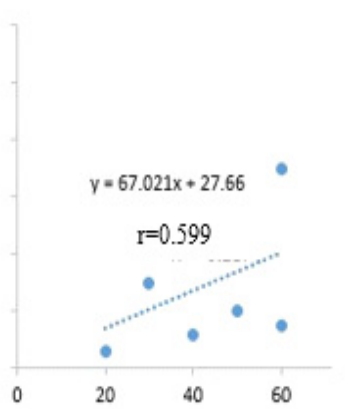

(f) Cost for waste collection(ZMW)

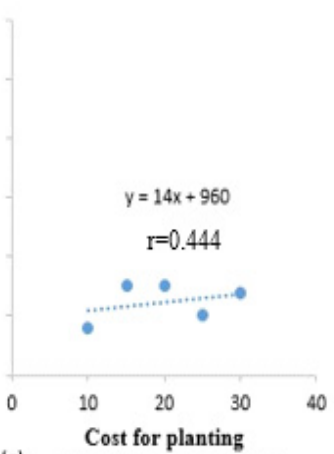

(c) $\begin{gathered}\text { Cost for planting } \\ \text { trees/regetables(ZMW) }\end{gathered}$
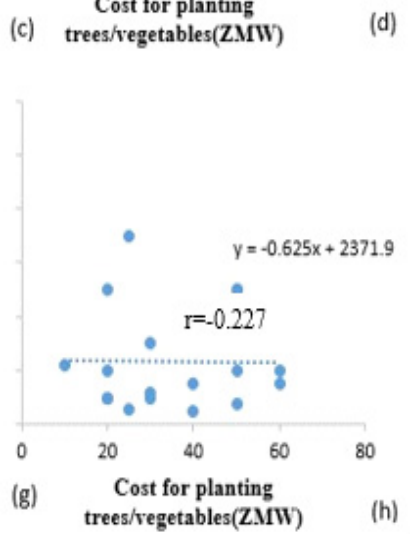

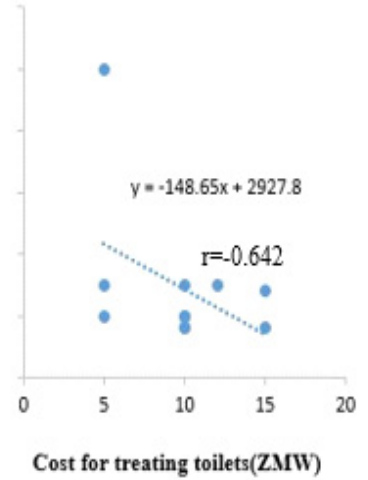

Cost for treating toilets(ZMW)

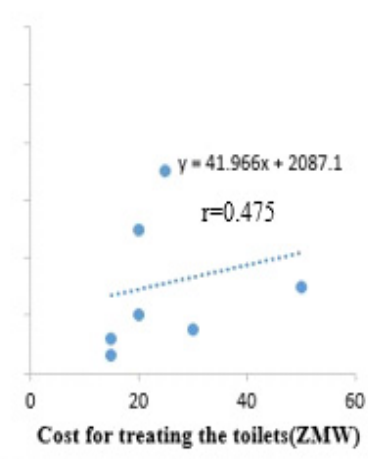

Figure 9. Scatter graphs showing the correlation between Monthly income and (a) cost for 
waste bins in Zone 98 (b) cost for waste collections in Zone 98(c) Cost for planting trees/vegetables in Zone 98 (d) Cost for treating toilets in Zone 98(e) Cost for waste bins in Zone 100 (f) cost for waste collection in Zone 100(g) Cost for planting trees/vegetables in Zone 100 (h) cost for treating the toilets in Zone 100

At 0.05 level of significance, the residential Zone where one came from had a significant influence on their willingness to pay for household practices sustaining environmental solutions $\left(X^{2}=2.1236\right.$; $\mathrm{p}$-value $\left.=0.0162\right)$. From the results, 95 out of 145 respondents (Table 5) were willing to pay for the transformation of their households but were not yet doing so because some respondents $(51 \%)$ thought that the government was responsible for paying the costs and only $49 \%$ of the residents (15 from Zone 98 and 45 from Zone 100) were able to pay for the transformation of environmental concerns into environmental solutions at the household level (Table 5).

Table 5. Chi-square test showing the association between residential income level and respondent's willingness to pay for household environment sustainability

\begin{tabular}{|c|c|c|c|c|c|c|c|c|c|}
\hline & Res] & & Zone100 & Zone98 & Total & & Value & D.F & P-value \\
\hline \multirow{4}{*}{$\begin{array}{l}\text { Willingness } \\
\text { to pay }\end{array}$} & \multirow[t]{2}{*}{ yes } & Count & 69 & 67 & 136 & \multirow{4}{*}{$\begin{array}{l}\text { Pearson Chi- } \\
\text { Square }\end{array}$} & \multirow{4}{*}{$3.636^{\mathrm{a}}$} & \multirow{4}{*}{2} & \multirow[t]{4}{*}{0.162} \\
\hline & & $\begin{array}{l}\text { Expected } \\
\text { count }\end{array}$ & 69.4069 & 66.5931 & 136 & & & & \\
\hline & \multirow[t]{2}{*}{ No } & Count & 5 & 4 & 9 & & & & \\
\hline & & $\begin{array}{l}\text { Expected } \\
\text { count }\end{array}$ & 4.59209 & 4.13791 & 6 & & & & \\
\hline \multirow[t]{2}{*}{ Total } & & & \multirow[t]{2}{*}{74} & \multirow[t]{2}{*}{71} & \multirow[t]{2}{*}{145} & Ratio & & & \\
\hline & & & & & & $\begin{array}{l}\text { Number of } \\
\text { Valid Cases }\end{array}$ & 145 & & \\
\hline
\end{tabular}

\section{Discussion}

\subsection{Sustainable Household Practices That Can Transform Environmental Concerns Into Environmental Solutions}

Sustainable household practices that transform environmental concerns into environmental solutions in Kanyama Ward 10 included the use of waste bins for solid waste disposal, paying for solid waste collection, planting trees and vegetables at their households, cleaning the surroundings, use of treated toilets and use of solar lights for lighting.

More residents in Zone 100 (high-income area) were engaged in environmentally sustainable household practices in Kanyama Ward 10 than residents in Zone 98 (low-income area). This shows that poor people are less environmentally conscious than rich people. The first and foremost sustainable development goal is to "eradicate poverty in all forms everywhere" (UN DESA, 2015). Urban planning programs must promote poverty eradication so that even the poor and vulnerable people may enjoy equal rights to economic resources and healthy living conditions. The study showed that low-income areas are more severely vulnerable to effects of 
environmental issues than the high-income areas. This is in line with Brundtland (1987) who viewed poverty and environmental problems in a broader perspective and expects poverty to be the major cause of environmental issues in low-income areas. Due to lack of sufficient resources and inadequate environmental knowledge, low-income residents tend to overuse every resource available to them when their survival is at stake. As a result, the overuse of the resources unsustainably can trigger destruction to the environment (Finco, 2009).

Increased monthly income does not translate into increased expenses towards environmental sustainability for low-income residents as long as the increase is not large enough to enable households to cross the threshold for economical sustainability into high income. Although residents in Zone 98 were willing to pay for environmental sustainability, every time there is a potential trade-off between environmental sustainability and household livelihood sustenance, the choice was usually tailored to household sustenance. For instance, more residents in Zone 98 depended on charcoal and firewood for domestic energy use instead of using solar lights which is a sustainable household practice. This type of energy promotes deforestation and introduces the greenhouse gas carbon dioxide into the atmosphere while removing the carbon sink in form of forests, albeit at a local level. This is contrary to sustainable development goal (SDG) 11 on sustainable cities and communities (UN DESA, 2015). The overall goal of sustainable development is the long-term stability of the economy and environment and it can only be realized through the integration and acknowledgement of economic, environmental, and social concerns throughout the decision-making process. It is very significant to realise that low income and environmental issues are interconnected. Low income among the residents puts stress on the environment through unsustainable household practices whereas environmental issues cause severe suffering to low-income people. In reality, the well-being of poor people is inseparably linked to the environment in terms of their livelihoods, health, and vulnerabilities (Bryceson, 2002). Hence, sustainable household practices can be enhanced by eradicating poverty in informal settlements.

\subsection{Cost for Transforming Environmental Concerns Into Environmental Solutions}

Residents in low income (Zone 98) areas focused more on economical sustainability than caring for their environmental sustainability in terms of securing sustainable waste disposal methods and improving household sanitation. The findings are congruent to the findings by World Bank Group (2015) that toilet treating fees were prohibitively high for most low-income households, which partially explained why many households could not appropriately maintain their toilet systems.

Generally, residents in high-income areas (Zone 100) spent more money on sustainable household practices that transform environmental issues into environmental solutions than residents in low-income areas (Zone 98) due to their high-income levels. Since residents in high-income areas have already attained economical sustainability, they could afford to be concerned about environmental sustainability as long as this did not affect their economic sustainability. This was in line with the report by Ombis, (2018) that in Nairobi, low and middle-income areas did not have waste collection systems in place while in high-income areas, private waste collection companies are booming and residents pay handsomely.

Levels of education of respondents in the study area significantly influenced their degree of engagement in household environmental sustainability. This is because education helps in 
changing people's mindset, attitudes and perceptions as regard their environment, and it broadens their understanding of environmental sustainability. This study has shown that in high residential areas more residents attained higher educational levels than residents in low-income areas, hence more sustainable household practices in Zone 100 than in Zone 98. The United Nations Education and Scientific Organization (2011) supported the findings of this study that education is a powerful tool that should be used toward building a more sustainable society that is better informed, has critical views and has wiser and more responsible people. Söderholm (2011) further articulated that many sustainable behaviours originate from the personal norm and environmental awareness that acts as a motivation and entail some kind of sacrifice from the individual because there are several costs attached to the green behaviour.

5.3 Towards a Framework That Can Enhance Sustainable Household Practices for Transforming Environmental Concerns in Informal Settlements Into Environmental Solutions

The following interventions were identified as factors that could contribute to sustainable household practices that can transform environmental concerns in informal settlements into environmental solutions in Zambia.

\subsubsection{Environmental Education (EE)}

Lack of environmental education in Kanyama Ward 10 contributed to unsustainable household practices because residents did not understand the need for environmental sustainability. EE was vital in imparting an inherent respect for nature amongst society and in enhancing public environmental awareness. UNESCO (2014) emphasized the role of EE in safeguarding future global developments of societal quality of life (QOL), through the protection of the environment, eradication of poverty, minimization of inequalities and insurance of sustainable development. Hence environmental education promotes sustainable household practices.

Sustainable household practices were also vital in transforming environmental concerns in informal settlements into environmental solutions, and they were dependent on one's knowledge and skills necessary to make in-depth decisions and actions that could address complex household environmental issues. In addition, environmental education was not only equivalent to schooling or formal education alone, but it also included non-formal and informal modes of instruction and learning (Singh, 2010). The non-formal and informal modes could be through posters, entertainment, and peer to peer education and by doing activities aimed at increasing awareness, participation and commitment to household environmental sustainability.

To ensure community participation and ownership of any environmental education program focus groups would be established that would incorporate all elements of the community. This was supported by the provision in the EMA Act No 3 of 2011 of the Government of Zambia that the citizen shall have access to environmental information to enable the citizen to make informed personal choices which encourages improved performance by industry and the Government and that every person living in Zambia has the right to a clean, safe and healthy environment (EMA, 2011). In line with the findings of Pacey (1990), formal education for women, in particular, was a precondition for change in sanitation behaviour. Environmental education was significant to make people respond to environmental problems; they could be well-informed about problems, equipped with skills and motivation to find a solution to those 
problems and to prevent new problems from happening. Phillips and Schweisfurth (2014) reported that most of the secondary school syllabuses in developing countries including Zambia do not emphasize environmental education and may eradicate the exposure to environmental aspects, therefore, there was need to include environmental education in school syllabuses as a compulsory subject from elementary grades.

\subsubsection{Planning and Creation of Engineered Dump Sites}

While the forces impacting on the growth of cities have changed dramatically in many parts of the world, there has been very little change in the planning systems which has contributed to urban problems (UN-Habitant, 2009). There was a need to change planning systems so that they can function as effective instruments of sustainable urban change, which are, capable of making settlements more environmentally sound and safe, more economically productive and more socially inclusive.

Local authorities, in particular, could use a range of principles and practices to integrate the environmental sustainability in urban planning which includes providing of environmental infrastructures like dump sites, water distribution pipes, sewage pipes and septic tanks. Secondly, environmental strategies for urban areas need to be supported by key underlying principles which should be elaborated in local area plans and must explain in detail how households in informal settlements could practice the principles in order to achieve household environmental sustainability.

The findings showed that unsustainable household practices were exacerbated by the lack of basic services in informal settlements. This indicated that Local Authorities do not have the policy to address the needs and priorities of people living in informal settlements which create great challenges for environmental planners and managers. The lack of dumping sites in the area was one of the contributors to unsustainable household practices hence, the creation of engineered dumping sites in the area would aid waste collection and transportation from households to specific areas which would improve environmental sustainability. Achieving this would involve the introduction of improved technologies and equipment which would be appropriate for and adapted to the local conditions. The engineered dumpsite would include waste sorting and recycling, reuse, sanitary landfilling leachate and treatment, and a buffer zone with gardens and farming that would shield the site from the surrounding. For better environmental sustainability, the local area plan should at least have one waste collection point located in each street in order to increase efficiency in waste collection.

5.3.3 Engaging Private Sectors and Non-Governmental Organization (NGOs) in Enhancing Environmental Sustainability

Concerning the engagement of private sectors and Non-governmental organizations (NGOs) in enhancing environmental sustainability, findings reveal that there has been very minimal involvement of the private sector and NGOs in the provision of municipal services that would enhance sustainable household practices in Kanyama Ward 10. There was only one solid waste collection company that was engaged to collect waste in the entire Ward which only used to collect the waste once a week. The Ward also lacks private sector involvement in the provision of adequate water and sanitation. Residents depended on water from wells and individually drilled boreholes which were not environmentally sustainable. Interactive planning and 
decision-making processes in Kanyama Ward 10 are needed to support private sector participation in urban governance and to co-ordinate this participation with municipalities. Pieterse (2000) commented that municipalities can strengthen urban governance in co-operation with the private sector by fostering partnerships and local economic development (LED) strategies that combine local skills, resources and ideas to stimulate the local economy and environmental infrastructure provision. Partnering with the private sector could: extend services into poorer or informal communities, provide safer workplaces, promote adoption of non-discriminatory employment policies, help the poor access credit, and boost investment in low-cost housing. The private sector will also seek partnerships with residents of informal settlements, NGOs and municipal government.

These collaborative ventures would involve information, education and community campaigns to ensure that residents of informal settlements are involved and have some ownership of programmes. They would also assist the poorest families through the provision of micro-finance (Franceys and Wietz, 2003). The adequate involvement of private sectors and NGOs would improve sustainable household practices, particularly on waste collection, water and sanitation provision. The private sector and NGOs would be engaged in providing waste banks which places value at every stage of the solid waste value chain and is mutually beneficial to all players as a sustainable model for waste management in the Ward. The objective was to drive the Ward towards zero waste. To achieve this, a framework emphasising on waste reduction, reuse, recycling and recovery is developed as a means of reducing disposal costs, reducing the burden on landfills and reducing environmental impacts (Figure 10). Part of the initiative would be to narrow the gap between recyclers and producers. This should encourage the sorting of waste at the source so that valuable materials can be easily collected. The incentive would be that the small tokens which accumulate overtime would be given to generators who sort their waste at source, the tokens could be redeemed through cash withdrawals or discounts on related services such as water and sanitation bills. Economizing separation of usable wastes would encourage residents to be separating waste at their households since they would know that they could sell the bottles or any other waste. Therefore, supportive efforts and programs in informal settlements to improve environmental quality should begin with the reduction of poverty in a way that contributes to environmental sustainability. This would involve planning and implementation of sustainable household practices in the Ward through effective coordination, collaboration and networking of different environmental actors which was critical in environmental sustainability in terms of having specific roles, responsibilities, functions and resources for environmental management.

Ballanty and Oalafse (2009) argued that informal settlements are an integral part of the urban environment where people are at a close interface with the environment. It was therefore important that urban managers and planners find ways of developing informal settlements that enhance household environmental sustainability. Figure 10 summarizes the framework that could enhance sustainable household practices for transforming environmental concerns in informal settlements into environmental solutions in Zambia. 


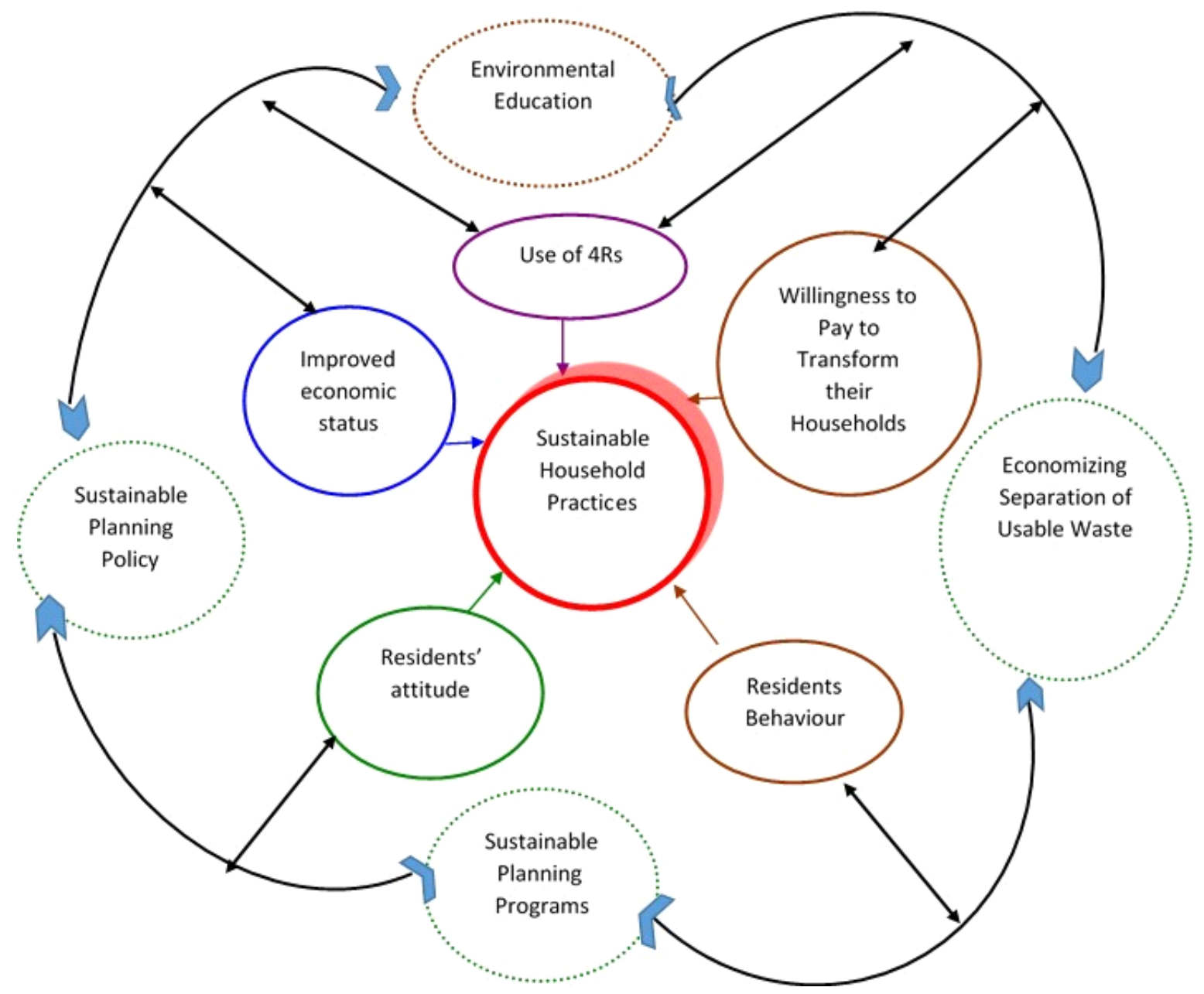

Figure 10. Framework towards sustainable household practices that transform environmental issues into environmental solutions in informal settlements

\section{Conclusion}

Generally, the major environmental issues in Kanyama Ward 10 were poor solid waste management, poor drainage systems, flooding, and lack of spaces for planting trees, intermittent water supply and poor access roads. These environmental concerns were more in Zone 98 than in Zone 100 because residents of Zone 98 engaged in a lot of unsustainable household practices like burning waste, disposing of waste in drainages, use of untreated latrines, use of charcoal, use of shallows wells and indiscriminate waste disposal than did residents in Zone 100. However, residents in Zone 100 were engaged in more sustainable household practices such as disposing of waste in waste bins, paying for waste collection, treating their latrines, using solar lights, planting trees and cleaning their surroundings than residents in Zone 98.

This research concluded that environmental sustainability was partly affected by the resident's monthly income but significantly affected by their education levels. Therefore, it is recommended that the Ministry of Education look into the provision of environmental education at elementary levels, engaging in public awareness campaigns by ZEMA and NGOs, creation of engineered waste disposal site by local authorities, improving streets, roads and 
environmental infrastructure through public-private partnership (PPP), improving residents income levels through the involvement of more private sectors and CBOs/NGOs in local economic development (LED) activities and economizing separated waste were appropriate measures for improving sustainable household practices in the study area. Policy on effective sustainable household practices should focus on infrastructure and physical planning that promote green behaviour at the household level. The policy should also be directed at individuals with a view to, directly and indirectly, influence their practices in the household.

\section{Acknowledgement}

We wish to thank all who provided support during the data collection for this study.

\section{References}

Bai, Z., \& Dent, D. (2009). Recent Land Degradation and Improvement in China. Royal Swedish Academy of Sciences, 38(3), 150-156. https://doi.org/10.1579/0044-7447-38.3.150

Bryceson, D. F. (2002). The scramble in Africa: Reorienting rural livelihoods. World Development, 30(5), 725-739. https://doi.org/10.1016/S0305-750X(02)00006-2

Brundtland, G. H. (1987). Report of the world commission on environment and development: "Our common future". New York: United Nations.

Bryman, A. (2012). Social Research Methods (4th ed.). Oxford University Press.

CSO. (2012). 2010 Census of Population and Housing National Analytical Report, Lusaka: CSO.

EMA. (2011). Environmental Management Act No. 12 of 2011, Lusaka.

Franceys, R., \& Weitz, A. (2003). Public-Private Community Partnerships in Infrastructure for the Poor. Journal of International Development, 15(8), 1092-1094. https://doi.org/10.1002/ jid. 1052

Faul, F., Erdfelder, E., Buchner, A., \& Lang, A. G. (2013). G*Power Version 3.1.2 [computer software]. Uiversität Kiel, Germany.

Finco, M. V. A. (2009). Poverty-environment trap: A nonlinear probit model applied to rural areas in the North of Brazil. American-Eurasian Journal of Agricultural and Environmental Science, 5(4), 533-539.

Gutberlet, J., \& Henrik J. (2016). Bridging weak links of solid management in informal settlements. The Journal of Environment \& Development, 26(1). https://doi.org/10.1177/ 1070496516672263

Kothari, C. R. (2004). Research methodology. Methods and techniques. New age international (p) Ltd, publishers.

Kaundal, R., \& Sharma, A. (2007). Problems of Household Waste Disposal. Palampur 176 062., 21(3), 199-201. https://doi.org/10.1080/09709274.2007.11905973

Ministry of Local Government, and ECZ. (2014). Lusaka City State of Environment Outlook. Moosavi, M. (2011). An introduction to environmental challenges of life in slum settlements of Tabriz. $2^{\text {nd }}$ international conference on humanities, historical and social sciences. IPEDR. IACSIT Press, Singapore.

Mwape, P. (2009). Impacts of floods on the socio-economic livelihoods of people: a case study of sikaunzwe community in Kazungula district of Zambia. Masters of Science thesis. Faculty 
of Natural and Agricultural Sciences, University of the Free State, South Africa.

Hunter, P. R., MacDonald, A. M., \& Carter, R. C. (2010). Water Supply and Health. PLOS Med, 7(11), e1000361. https://doi.org/10.1371/journal.pmed.1000361

Mutesu, L. M. (2015). An assessment of the quality and microbiological quality of domestic water supply in Peri-Urban areas of Lusaka District. Masters of Public Health thesis. Department of Public Health, School of Medicine, University of Zambia, Zambia.

Nkwachukwu, O. I., Chima, C. H., Ikenna, A. O., \& Albert, L. (2013). Focus on potential environmental issues on plastic world towards sustainable plastic recycling in developing countries. International Journal of Industrial Chemistry, 34(4). https://doi.org/10.1186/22285547-4-34

Olijide, O. (2010). Urban Poverty and Environmental Conditions in Informal Settlements in Adejunle, Lagos Nigeria. Department of Geography and Planning, Lagos State University.

Pieterse, E. A. (2000). Participatory Urban Governance: Practical Approaches, Regional Trends and UMP Experiences. Nairobi: United Nations Centre for Human Settlements (UNCHS) (Habitat).

Phillips, D., \& Schweisfurth, M. (2014). Comparative and international education: An introduction to theory, method, and practice. New York: A\&C Black.

Rinkesh, G. (2009). Conserve energy future. Be green, stay green.

Saunders, P. (1980). Urban politics: A sociological approach. London: Penguin.

Singh, J. P. (2010). United Nations Educational, Scientific, and Cultural Organization (UNESCO): Creating norms for a complex world. New York: Routledge. https://doi.org/ $10.4324 / 9780203838587$

Šmejkalova, J., Jacob, V., Hodacova, L., Fiala, Z., \& Vellappally, S. (2003). The Influence of Smoking on Dental and Periodontal Status. Charles University in Prague, Medical Faculty in Hradec Kralove Czech Republic.

UNEP. (2011). Towards a green economy: Pathways to sustainable development and poverty eradication. UNEP, Nairobi.

UNDESA. (2015). World urbanization prospects: The 2014 revision. New York: UNDESA.

UN-Habitat. (2008). The State of African Cities: A Framework for Addressing Urban Challenges in Africa, Nairobi- Kenya.

UN-Habitat. (2009). Planning Sustainable Cities: Policy Directions. Global Report on Human Settlements 2009. United Nations.

UN-Habitant. (2011). Participatory Slum Upgrading programme: Slum Situation Analysis.

United Nations Education and Scientific Organization. (2011). Education for Sustainable Development (Online) Retrieved June 15th 2013 from World Wide Web: http:// www.unesco.org/education/esd/shtm

Wasongo, J. (2014). Improving Households Knowledge and Attitude on Water, Sanitation, and Hygiene Practices through School Health Programme in Nyakach, Kisumu County in Western Kenya. https://doi.org/10.1155/2014/958481

World Bank. (2007). The Slum Networking Project in Ahmedabad: Partnering for change. Washington, DC: World Bank. 


\section{Copyrights}

Copyright for this article is retained by the author(s), with first publication rights granted to the journal.

This is an open-access article distributed under the terms and conditions of the Creative Commons Attribution license (http://creativecommons.org/licenses/by/4.0/) 